\title{
THE CHEMICAL COMPOSITION AND POLLUANTS CONTENT OF SOME ECOLOGICAL AND CONVENTIONAL GREEN FORAGE SOURCES FOR DAIRY COW FEED
}

\author{
Gherasim NACU ${ }^{1}$, Mircea POP ${ }^{1, *}$, Daniel SIMEANU ${ }^{1}$, Cristina RADU-RUSU ${ }^{1}$, \\ Roxana ZAHARIA ${ }^{1}$, Vasile VINTIL $\check{A}^{2, *}$ \\ `E-mail: popim@uaiasi.ro; vasilevintilais@yahoo.com
}

Received: Feb. 25, 2020. Revised: Mar. 23, 2020. Accepted: Mar. 26, 2020. Published online: Mar. 31, 2021

\begin{abstract}
The quality of feed is very important in dairy milk production. The aim of the current paper was a comparative characterisation in terms of crude chemical composition, $\mathrm{Ca}$ and $\mathrm{P}$, heavy metals $(\mathrm{Pb}, \mathrm{Cd}, \mathrm{Zn}, \mathrm{Cu})$, nitrates, nitrites and pesticides, for the natural meadow and green alfalfa, cultivated in ecological and conventional systems, utilised for feeding dairy cows. Sampling and analysis were performed according to established standards and working methods: drying for dry matter (DM); calcination for crude ash (C Ash); Kjeldahl method for crude protein (CP); Soxhlet method for crude fat or ether extract (EE), spectrophotometry for $\mathrm{P}$, nitrates and nitrites; atomic absorption spectrometry for $\mathrm{Ca}, \mathrm{Pb}, \mathrm{Cd}, \mathrm{Cu}$ and $\mathrm{Zn}$; gas-chromatography for pesticides. For alfalfa, the highest values in the ecological system were for $\mathrm{C}$ Ash (12.68\%), EE (2.50\%), NFE (35.78\%) and $\mathrm{Ca}(1.79 \%)$. For the natural meadow,
\end{abstract}

the highest values in the ecological system were for DM $(25.72 \%)$, OS $(89.32 \%)$, EE $(2.76 \%)$, NFE (45.27\%) and $\mathrm{Ca}(0.70 \%)$. The toxic heavy metal content was below the limits allowed ( $1 \mathrm{mg} / \mathrm{kg} \mathrm{Cd}$ and $30 \mathrm{mg} / \mathrm{kg} \mathrm{Pb}$ ). For $\mathrm{Pb}$ the values determined from the two feeds were between $0.06 \mathrm{mg} / \mathrm{kg}$ and $0.16 \mathrm{mg} / \mathrm{kg}$ and for $\mathrm{Cd}$ between $0.007 \mathrm{mg} / \mathrm{kg}$ and $0.02 \mathrm{mg} / \mathrm{kg}$. The pesticides residuum was under the detection limit of $0.05 \mathrm{mg} / \mathrm{kg}$ $\mathrm{DM}$ for organo-chlorinated pesticides and $0.001 \mathrm{mg} / \mathrm{kg}$ for organo-phosphoric pesticides. All the studied forages were safe regarding pollutants (heavy metals, nitrites, nitrates and pesticides), but statistical differences existed between the production systems, such that the ecological system seems to be better.

Keywords: chemical composition; ecological system forages; heavy metals; pollutants.

\footnotetext{
1 University of Agricultural Sciences and Veterinary Medicine of lasi, Faculty of Animal Sciences, 3 Mihail Sadoveanu Alley, 700490 lasi, Romania

${ }^{2}$ Cattle Breeding Research Station from Dancu, lasi - 9 Ungheni Road, 707252 lasi, Romania
} 


\section{INTRODUCTION}

Knowledge of the chemical composition of each feed is mandatory in order to be able to prepare feed rations for dairy cows. There are recent data on alfalfa (Mielman et al., 2017, Jadviga Andrzejewska et al., 2020;) and meadow (Cop et al., 2019; Simic et al., 2019; Martin et al., 2020), but the values differ depending on the variety, area, climate, and soil (Moreira and Fageria, 2010; Ulger and Kaplan, 2016; Cacan etal., 2018) and permanent determinations are required. Many studies have shown that products obtained from organic farming (including milk) have a much lower risk of pollution compared to those from conventional agriculture (Worthington Virginia, 2001; Rembialkowska, 2004; Leste, 2006), being safer for human consumption. Milk is a food with high nutritional value, rich in nutrients, and recommended for daily consumption (Givens, 2007). Ecological cow milk can be obtained only by feeding the dairy cows with fodder resulting from ecological agriculture. Pollutants pass from the soil to plants (Haarstad, 2012) and reach the final consumer through the food chain (Neamţu et al., 2007; Lapierre et al., 2019). They can get into milk (Miclean et al., 2018; Aydin et al., 2019; Memon et al., 2019) and into the human body. Some pollutants (heavy metals) remain in animal organisms (Khan et al., 2018) and can cause serious disease in humans (Coon et al., 2006). For these reasons, our team determined the chemical composition and the level of pollution for two feeds used to obtain organic milk, compared to the conventional production system.

\section{MATERIALS AND METHODS}

The chemical composition for natural meadow was determined at the beginning of the flowering stage and for green mass alfalfa at the beginning of budding. Samples for laboratory analysis were gathered in accordance with the current standards (SR EN ISO 6497:2005; SR ISO 6498:2001), and for each element five determinations were made.

The dry matter content (DM) was determined by drying the samples at $105^{\circ} \mathrm{C}$ for 6 hours, in an ESAC 50 type electric drying oven. The operation was repeated until a constant mass was obtained, in accordance with standard SR ISO 6496:2001 and SR ISO 712:2010.

Crude ash (C Ash) was determined in accordance with standard ISO 2171:2010 and AOAC 1990, by calcinations of samples at $550^{\circ} \mathrm{C}$, using a Superterme STC 611.06 calcination oven.

Organic substance content (OS) was determined as the difference between the DM and ash.

Crude protein $(\mathrm{CP})$ was determined using the Kjeldahl method (ISO 59831:2006).

Determination of the crude fat or ether extract (EE) was realised by extraction with organic solvents (petroleum ether) using the indirect Soxhlet method, in accordance with ISO 6492:2001 and utilising the Solvent Extractor SER 148VELP device.

Determination of crude fibre (CF) was realised in accordance with SR EN ISO 6865:2002. The semi-automatic method for fibres extraction by a VELP Five 6 was used, and the reagents were: 
hydrochloric acid $0.5 \mathrm{~mol} / \mathrm{l}$, sulphuric acid $0.13 \mathrm{~mol} / \mathrm{l}$, acetone, n-octanol antifoaming agent, and acetone.

Determination of the nutritional parameters helped us to calculate the quantity of nitrogen-free extract (NFE) substances, using the following formula:

$\mathrm{NFE} \%=\mathrm{OS} \%-(\mathrm{CP} \%+\mathrm{EE} \%+\mathrm{CF} \%)$

The fibres content was determined by titration with neutral detergent in accordance with standard SR EN ISO 16472:2006. Determination of acid detergent fibre was realised respecting standard SR EN ISO 13906:2008.

The content of $\mathrm{P}$ was determined by the spectrophotocolorimetric method using molybdovanadate reagent at a wavelength of $430 \mathrm{~nm}$ in a Shimadzu UV Mini 1240 spectrophotometer. The calibration curve was drawn at 5 points by preparation from standard phosphorus solution of some solutions with different phosphorus concentrations: $5,10,15,20$, 25, 30 and $40 \mathrm{mg} / \mathrm{l}$.

The Ca content was determined by using the atomic absorption spectrometry method in accordance with SR EN ISO 6869:2002 using an AA-6300 Shimadzu atomic absorption spectrometer with flame, at a wavelength of $422.6 \mathrm{~nm}$, in comparison with the lanthanum-caesium control solution. The calibration curve was designed at 3 points by preparation from calcium standard solution of some solutions with different concentrations: $0.5,1.5,2.0 \mathrm{mg} / 1$.

The heavy metals content $(\mathrm{Pb}, \mathrm{Cd}$, $\mathrm{Cu}$ and $\mathrm{Zn}$ ) was determined in accordance with SR EN 14082:2003 and AOAC, 1990 , by using the atomic absorption spectrometric method (AAS) on a GBCAvanta spectrometer. Calibration curves for lead were realised at 5 points $(0.5 ; 1$; $2.5 ; 5$ and $7.5 \mathrm{mg} / \mathrm{l})$, for cadmium at 5 points $(0.2 ; 0.5 ; 1 ; 1.5$ and $2 \mathrm{mg} / \mathrm{l})$, for copper at 3 points $(1 ; 2$ and $4 \mathrm{mg} / \mathrm{l})$ and for zinc at 4 points $(1 ; 2 ; 3$ and $4 \mathrm{mg} / \mathrm{l})$.
The wavelengths at which the concentrations of the metals were determined were as follows: $\mathrm{Pb}, \lambda=$ $217 \mathrm{~nm} ; \mathrm{Cd}, \lambda=228.8 \mathrm{~nm} ; \mathrm{Cu}, \lambda=$ $324.7 \mathrm{~nm}$; $\mathrm{Zn}, \lambda=213.9 \mathrm{~nm}$ (Nacu et al., 2018).

Determination of the organochlorinated and organo-phosphoric pesticides residuum was realised by the gas-chromatography method, in accordance with standard SR EN ISO 14181:2001, SR EN ISO 14182:2001 for nutrients. As standard solution, a mix of 80 organo-chlorinated and organophosphoric pesticides was utilised.

Nitrates and nitrites were determined in accordance with SR 13175:1993. The method consisted in the extraction of nitrites from the sample for analysis by deproteinisation of the extract and highlighting through a colouration reaction in red nuances of nitrites, with sulfanilamide and N-(1-naphthyl) ethylenediamine dihydrochloride. Photocolorimetry was realised at a wavelength of $538 \mathrm{~nm}$. Nitrates were determined by reduction of those nitrites in the presence of cadmium followed by a colouring reaction and colorimetry. The spectrophotometer Shimadzu UV Mini 1240 was also used.

The data obtained were statistically processed and interpreted. The position and variation estimators (arithmetic mean, variance, standard deviation of mean and variation coefficient) were calculated. The differences between the two production systems were established using the statistical software IBM SPSS 21.0 through Tukey test with two variables, that is, the T-test (2-tailed).

\section{RESULTS AND DISCUSSION}

The content of DM of natural meadow gathered at the beginning of flowering from the conventional 


\section{Gh. NACU, M. POP, D. SIMEANU, Cristina RADU-RUSU, Roxana ZAHARIA, V. VINTILĂ}

system was $16.81 \%$ in the $1^{\text {st }}$ year and $15.31 \%$ in the $2^{\text {nd }}$ year, values below the limits cited in the literature of 17.2\% (Pop et al., 2006; Jarrige et al., 1986) 24.12\% (Burlacu et al., 2002). The mean values obtained for samples from the ecological system $(25.72 \%$ in the $1^{\text {st }}$ year and $22.58 \%$ in the $2^{\text {nd }}$ year) exceed the upper limit of the mentioned interval. The differences between the two systems were very significant (Table 1) and are due to the different time of forage harvesting. In the conventional system, the harvested plants were in the beginning phase of sprouting, while in the ecological system, the harvested plants were in the flowering phase.

The DM content of green mass alfalfa (mean values), before budding, both for samples from the ecological system (20.13\% and $25.8 \%$ ) and for those gathered from the conventional system (21.89\% and $26.32 \%)$, are above the maximum limit of the interval found in the literature, which is $14.4 \%$ (Jarrige et al., 1986) and 15\% (Pop et al., 2006). The statistical differences between the two systems were insignificant for both research years. The alfalfa samples were harvested in the first year when the plants were at the beginning of flowering, while in the second year the harvest was done later, in the vegetation phase at the end of flowering.

Regarding the Ash content from natural meadow, the mean values (11.58\% and $10.78 \%$ ) for the analysed samples from the conventional system in the two consecutive years exceeded the maximum interval value of $9.4 \%$ (Kaya et al., 2004) and 10.3\%, and the values of $6.07 \%$ and $7.02 \%$ obtained for the ecological system are below the minimal value of the mentioned interval. The statistical differences between the two systems were very significant for both research years. The Ash content of green mass alfalfa had mean values which were within the variation limit of $8 \%$ (Preston, 2010) and $12.9 \%$ (Jarrige et al., 1986), both for samples gathered from ecological system and for those gathered from the conventional system. The statistical differences between the two systems were very significant for both research years.

For the OS content of natural meadow, the mean values of $81.31 \%$ and $80.67 \%$ found for samples gathered from the conventional system and respectively of $89.32 \%$ and $87.37 \%$ found for the samples gathered from the ecological system were below the minimal limit of the interval cited in the literature of $89.7 \%$ (Avci et al., 2006) and 90.7\% (Kaya et al., 2004). The statistical differences between the two systems were significant for the $1^{\text {st }}$ year and for the $2^{\text {nd }}$ year. The mean values for the OS content of green mass alfalfa were of $86.18 \%$ and $82.12 \%$ for samples gathered from the conventional system and $81.65 \%$ and $81.56 \%$ for the ones gathered from the ecological system, and the statistical differences between the two systems were distinctly significant for the $1^{\text {st }}$ year and insignificant for the $2^{\text {nd }}$ year of production. 


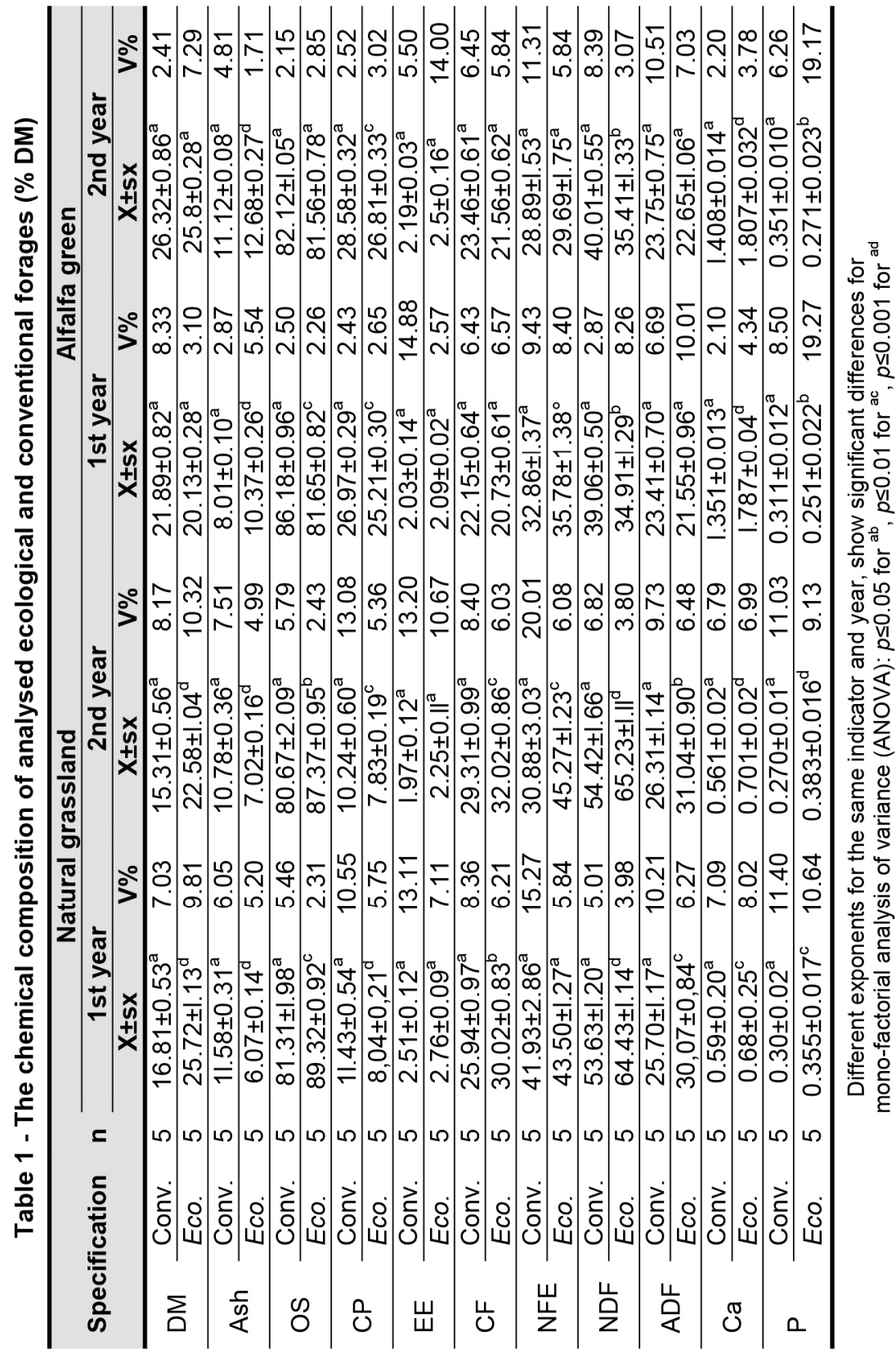

The CP content of green mass alfalfa before budding, with mean values of $25.21 \%$ and $26.81 \%$ for samples gathered from the ecological system, were within the limits found in the literature of $19 \%$ and $25.6 \%$ (Preston, 2010), while the mean values established for the samples 


\section{Gh. NACU, M. POP, D. SIMEANU, Cristina RADU-RUSU, Roxana ZAHARIA, V. VINTILĂ}

gathered from the conventional system $(26.97 \%$ and $28.58 \%)$ exceeded the maximum limit of the abovementioned interval. The statistical differences between the two systems were distinctly significant for both research years.

In the case of EE for natural meadows, the identified mean values of $2.51 \%$ and $1.97 \%$ for the analysed samples from the conventional system and $2.76 \%$ and $2.55 \%$ for those from the ecological system are within the limits presented in the literature of $1.9 \%$ (Kaya et al., 2004) and $4.5 \%$ (Avci et al., 2006). The statistical differences between the two systems were insignificant for both years of study.

The mean values established for the content of $\mathrm{EE}$ in green mass alfalfa were $2.03 \%$ and $2.19 \%$ for samples gathered from the conventional system and $2.09 \%$ and $2.75 \%$ for those gathered from the ecological system. Also in this case, the statistical differences between the two systems were insignificant for both years of study.

The interval between $27.2 \%$ (Jarrige et al., 1986; Pop et al., 2010) and $31 \%$ (Kaya et al., 2004) included the mean values established in our own research for the $\mathrm{CF}$ content of natural meadow: $25.94 \%$ and $29.31 \%$ for samples gathered from the conventional system, as well as the $30.02 \%$ in the $1^{\text {st }}$ year for the ecological system. However, the value of $32.02 \% \mathrm{CF}$ found in the samples from the ecological system in the $2^{\text {nd }}$ year was higher than the maximum limit from the literature. The statistical differences between the two systems were distinctly significant.

In the case of CF content in the green mass alfalfa before budding, the values established for samples gathered from the ecological system, as well as those from the conventional system, were within the variation limit of $20.1 \%$ (Jarrige et al., 1986) and $28.0 \%$ (Preston, 2010). The statistical differences between the two systems for this parameter were insignificant for both research years.

The NFE substances from natural meadow were between $41.93 \%$ and $30.88 \%$ for the samples gathered from the conventional system and between $48.50 \%$ and $45.27 \%$ for those from the ecological system. The statistical differences between the two systems were insignificant for the $1^{\text {st }}$ year and distinctly significant for the $2^{\text {nd }}$ year.

The NFE content of alfalfa was between $32.86 \%$ and $28.89 \%$ for the samples gathered from the conventional system and between $35.78 \%$ and $29.69 \%$ for those from the ecological system, the statistical differences between the two systems being significant for the $1^{\text {st }}$ year and insignificant for the $2^{\text {nd }}$ year of this study. The differences in raw chemical composition highlighted in the two feeds studied, in relation to the production system (conventional versus ecological), are determined more by the age of the plants at harvesting and not by the production system. 
The mean values of $64.43 \%$ and $65.23 \%$ for NDF from natural meadow for samples gathered from the ecological system are above the maximum limit of the interval found in the literature of $50.1 \% \mathrm{NDF}$ (Kaya et al., 2004) and 58.8\% NDF (Avci et al., 2006) and the values of $53.63 \% \mathrm{NDF}$ and $54.42 \% \mathrm{NDF}$ for samples gathered from the ecological system are within the mentioned interval. The statistical differences between the two production systems are very significant.

The mean values of NDF from alfalfa oscillated between $39.06 \%$ and $40.01 \%$ for the analysed samples from the conventional system and between $34.9 \%$ and $35.41 \%$ for those from the ecological system. The statistical differences between the systems were significant for both years of study.

For the ADF content of natural meadow, the mean values were between $30.07 \%$ and $31.04 \%$ for the samples gathered from the ecological system and between $25.70 \%$ and $26.31 \%$ for those gathered from the conventional system, the statistical differences between the two systems being significant.

The ADF content of the analysed alfalfa was situated below the minimal value of variation limit of 28\% and 35\% (Preston, 2010). The statistical differences between the two systems for this parameter were insignificant for both years of study.

The $\mathrm{Ca}$ content of the natural meadow, with mean values both for the samples gathered from conventional system $(0.59 \%$ and $0.56 \%$ ) and for those from the ecological system $(0.69 \%$ and $0.70 \%)$, were between the limits of $0.65 \%$ (Pop et al., 2006; Jarrige et al., 1986) and $0.92 \%$ (Burlacu et al., 2002), the statistical differences being distinctly significant for the $1^{\text {st }}$ year and very significant for the $2^{\text {nd }}$ year. The higher concentration of $\mathrm{Ca}$ found in organically produced feed is caused by the lower growth rate of the plants and the natural balance of soil microorganisms.

The $\mathrm{P}$ content of natural meadow was $0.30 \%$ and $0.27 \%$ for samples gathered from the conventional system, being slightly under the minimal value of the interval found in the literature, while the values of $0.36 \%$ and $0.38 \%$ for samples gathered from the ecological system were between the variation limits of $0.35 \%$ (Jarrige et al., 1986) and $0.39 \%$ (Burlacu et al., 2002). The statistical differences between the two systems were distinctly significant in the $1^{\text {st }}$ year and very significant in the $2^{\text {nd }}$ year.

The $\mathrm{Ca}$ content of green mass alfalfa before budding for samples gathered from the ecological system were above the upper limit found in the literature, at $0.40 \%$ and $1.65 \%$ (Jarrige et al., 1986). The mean values for samples gathered from the conventional system were between the above-mentioned limits, and the statistical differences between the two systems were very significant for both years analysed.

The statistical differences found between the two systems for this parameter were significant for both years of study. 


\section{Gh. NACU, M. POP, D. SIMEANU, Cristina RADU-RUSU, Roxana ZAHARIA, V. VINTILĂ}

All the mean values obtained for the natural meadow and alfalfa concentrations of toxic heavy metals $(\mathrm{Pb}$ and $\mathrm{Cd})$ were below the maximum limit imposed by Reg. EU, $1275 / 2013(30 \mathrm{mg} \mathrm{Pb} / \mathrm{kg}$ and $1 \mathrm{mg}$ $\mathrm{Cd} / \mathrm{kg}$ fodder with $12 \%$ moisture). The obtained results together with the statistical significance of the differences between the concentrations found in the samples gathered from the two production systems are presented in Table 2.

In the case of the $\mathrm{Pb}$ concentration of natural meadow, the mean values were below the limit presented in the literature of $2.49 \mathrm{mg}$ $\mathrm{Pb} / \mathrm{kg} \mathrm{DM}$ (Sothen, 2001) and $6.4 \mathrm{mg}$ $\mathrm{Pb} / \mathrm{kg} \mathrm{DM}$ (Bianu and Nica, 2004). The statistical differences between the two production systems were distinctly significant for both research years.

For the $\mathrm{Cd}$ concentration in the analysed samples of natural meadow, the majority of the established mean values were below the limit found in the literature, the exception being samples gathered from the conventional system in the $1^{\text {st }}$ year, which were in the interval of 4.3 $15.7 \mathrm{mg} \mathrm{Cd} / \mathrm{kg} \mathrm{DM}$ (Miloș and Drinceanu, 1980). The statistical differences between the two systems for this parameter were very significant for both research years. For the $\mathrm{Zn}$ concentration in the case of natural meadow, the recorded differences between the two systems were insignificant from the statistical point of view.

The higher content of $\mathrm{Pb}$ in the analysed samples from the ecological system could be explained by the fact that the meadow from which samples were gathered is transited by the national road $\mathrm{DN} 282$. The higher $\mathrm{Cu}$ concentration in the analysed samples from the ecological system could be explained by the reduced growth rate of the plants. The banning of the use of fertilisers based on phosphates (the main source of contamination with $\mathrm{Cd}$ ) in the frame of the ecological production system could explain the lower rate of $\mathrm{Cd}$ in the samples from this system.

The established mean values for the $\mathrm{Pb}$ concentration of green mass alfalfa were below the limits presented in the literature of $0.198 \mathrm{mg}$ $\mathrm{Pb} / \mathrm{kg} \mathrm{DM}$ and $0.433 \mathrm{mg} \mathrm{Pb} / \mathrm{kg} \mathrm{SU}$ (Li et al., 2008), the statistical differences between the production systems being very significant in both research years.

The $\mathrm{Cd}$ concentration in the analysed samples of green mass alfalfa had mean values below the limit of $0.045 \mathrm{mg} \mathrm{Cd} / \mathrm{kg} \mathrm{DM}$ and $0.328 \mathrm{mg} \mathrm{Cd} \mathrm{kg} \mathrm{SU} \mathrm{(Trincă} \mathrm{et} \mathrm{al.,} \mathrm{2008).}$ The statistical differences between the two systems were very significant for both years of study. The lower concentration of organic fodder is due to the ban on the use of phosphate fertilisers in this production system.

For the $\mathrm{Cu}$ and $\mathrm{Zn}$ concentrations, the statistical differences between the two systems were very significant. The higher concentration of $\mathrm{Cu}$ for feed obtained in the conventional system is due to the accelerated production of biomass in this system.

The nitrates and nitrites content 
of natural meadow and ecological alfalfa recorded values that were significant, statistically speaking, and lower than the samples gathered from the conventional system.

The totality of the analysed
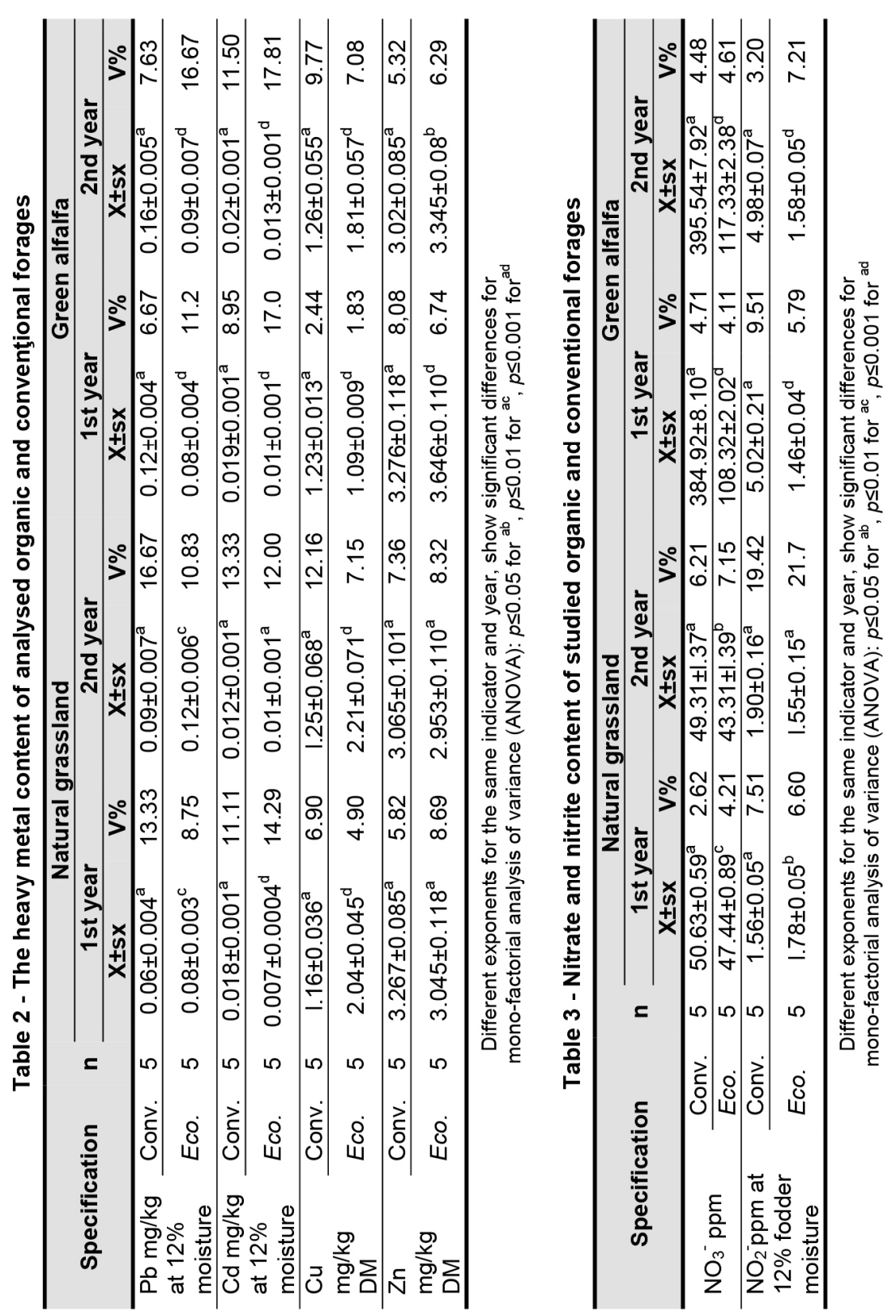

samples, for both research years, for the nitrites content of the two forages (Table 3) were situated below the maximum admissible limit of $15 \mathrm{ppm}$ $\mathrm{NO}_{2}^{-}$fodder with $12 \%$ moisture, as imposed by Regulation 575/2011. 
The nitrites $\left(\mathrm{NO}_{2}{ }^{-}\right)$concentration of natural meadow had mean values between 1.56 and $1.90 \mathrm{mg} / \mathrm{kg}$ at $12 \%$ moisture for the conventional production system, and between 1.78 and $1.55 \mathrm{mg} / \mathrm{kg}$ for the ecological production system.

The nitrites $\left(\mathrm{NO}_{2}{ }^{-}\right)$content of green mass alfalfa had mean values between 5.02 and $4.98 \mathrm{mg} / \mathrm{kg}$ at $12 \%$ moisture for the conventional system and $1.46-1.58 \mathrm{mg} / \mathrm{kg}$ for the ecological one, the differences between systems being very significant.

The ban on the use of fertilisers based on nitrogen in the frame of ecological production systems could explain the lower rate of these compounds in the analysed natural meadow belonging to this system.

Gas chromatographic analysis of the concentration of organochlorinated and organo-phosphoric pesticides from samples of natural meadow and green mass alfalfa gathered from both systems, conventional and ecological, highlight the fact that the pesticides residuum was under the detection limit of 0.05 $\mathrm{mg} / \mathrm{kg} \mathrm{DM}$ for organo-chlorinated pesticides and $0.001 \mathrm{mg} / \mathrm{kg}$ for organo-phosphoric pesticides.

\section{CONCLUSION}

The crude chemical composition fluctuated more depending on the feed analysed and less depending on the field of production.

In the ecological system, the highest values for both feeds were for EE (with $0.25 \%$ for natural meadow and with $0.18 \%$ for alfalfa); for NFE (with $7.98 \%$ for natural meadow and with $0.18 \%$ for alfalfa) and for $\mathrm{Ca}$ (with $0.2 \%$ for natural meadow and with $0.41 \%$ for alfalfa).

The highest values obtained in the conventional system were only for CP (with $2.90 \%$ for natural meadow and $1.76 \%$ for alfalfa).

Both feeds were safe in terms of heavy metal content. The maximum concentration for $\mathrm{Cd}$ was 50 times less than the maximum allowed limit $(1 \mathrm{mg} / \mathrm{kg})$, for $\mathrm{Pb}$ it was 187.5 times less than the maximum allowed limit $(30 \mathrm{mg} / \mathrm{kg})$ and for $\mathrm{Cu}$ it was 22.6 times less than the maximum permissible limit $(50 \mathrm{mg} / \mathrm{kg})$.

The maximum level of nitrites in the analysed feed was 2.98 times lower than the maximum allowed limit $(15 \mathrm{mg} / \mathrm{kg})$ for alfalfa obtained in a conventional system and with fertiliser.

No pesticide residues were detected in the analysed feed.

The most relevant indicators from the ecological point of view (content of heavy metals, pesticides, nitrites and nitrates) show that the studied forages for dairy cow feed to obtain ecological milk were within the quality parameters imposed with this system.

\section{REFERENCES}
Association of Official Analytical Chemists (1990). Ash of animal feed (942.05) Official methods of analysis, $15^{\text {th }}$ edition, p. 70 .


Avci, M., Kaplan, O., Yertürk, M. \& Aslan, M. (2006). Nutrient and botanical composition of pasture in Ceylanpinar agriculture farm, YYÜ Vet Fak Derg, 17(1-2): 9-13.

Bianu, E. \& Nica, D. (2003-2004). Monitoring the effect of cadmium on birds in an area heavily polluted with heavy metals. Lucrari St. USAMVB Timisoara, Seria C, XLVI-XLVII, pp. 514-520.

Burlacu, Gh., Cavache, A. \& Burlacu, R. (2002). Productive potential of fodders and their usage (in Romanian), Edit. Ceres, Bucureşti.

Givens, D. I. (2005). The role of animal nutrition in improving the nutritive value of animal-derived foods in relation to chronic disease. Proc.Nutr.Soc., $\quad$ 64(3): 395-402, https://doi.org/10.1079/pns2005448

Jarrige, R., Demarquilly, C., Dulphy, J. P., Hoden, A., Robelin, J., Beranger, C., ...\& Petit, M. (1986). The INRA "Fill Unit" System for Predicting the Voluntary Intake of Forage-Based Diets in Ruminants: A Review. J.Anim.Sci., 63(6): 17371758, https://doi.org/10.2527/jas19 86.6361737x

Katayama, N., Osada, Y., Mashiko, M., Baba, Y. G., Tanaka, K., Kusumoto, Y., \& Natuhara, Y. (2019). Organic farming and associated management practices benefit multiple wildlife taxa: A large-scale field study in rice paddy landscapes. J.Appl.Ecol., https://doi.org/10.1111/13652664.13446

Kaya, I., Öncüer, A. \& Ünal, Y. (2004). Nutritive value of pastures in Kars District I. Botanical and nutrient composition at different stages of maturity. Turk.J.Vet.Anim.Sci., 28(2): 275-280.

Li, Y., McCrory, D. F., Powell, J. M., Saam, H. \& Jackson-Smith, D. (2005). A survey of selected heavy metal concentrations in Wisconsin Dairy Feeds. J. Dairy Sci., 88(8): 2911-2922, https://doi.org/10.3168/ jds.s0022-03 02(05)72972-6
Liao, J., Xu, Q., Xu, H. \& Huang, D. (2019). Natural farming improves soil quality and alters microbial diversity in a cabbage field in Japan. Sustainability, 11(11): 3131, https://doi.org/10.3390/su11113131

Milos, M. \& Drinceanu, D. (1980). Mineral nutrition of animals (in Romanian), Edit. Ceres, Bucureşti.

Nacu, G., Bologa, M., Pop, C., Boisteanu, P.C., Simeanu, D., Doliş, M.G. \& Donosă, R. (2018). Research on chemical composition and nutritive value of green fodder used in ecological production of eggs for consumption. Rev.Chim., 69(3): 682-687. https://doi.org/10. 37358/rc. 18.3.6175

Pintilie, O., Andrieş, C., Cosma, A., Zaharia, M., Drochioiu, G., Vasilache, V. \& Sandu, I. (2015). The influence of dinitrophenolic pesticides on the viability of plants. Rev. Chim., 66(9): 1321-1326.

Preston, R.L. (2010). What's the feed composition value of that cattle feed? Beef Magazine, Mar. 01, pp. 11-17.

Sothen, F. von (2001). Heavy metal input on farmland - an indicator for a sustainable agricultural system, Edit. Shaker Verlag, Germany, 10: 363369.

SR 13175:1993, Fodders. Determination of nitrites and nitrates content.

SR EN ISO 13906:2008, Fodders. Determination of acid fibre detergent content (ADF) and sulphuric lignine (ADL).

BS EN 14082:2003, Foodstuffs. Determination of trace elements. Determination of lead, cadmium, zinc, copper, iron and chromium by atomic absorption spectrometry (AAS) after ash drying. (n.d.), https://doi.org/10.3403/02784276u

SR EN ISO 14181:2001, Fodders. Determination of organo-chlorine pesticide residues. Gas chromatographic method.

SR EN ISO 14182:2001, Fodders. Determination of organo-phosphorus 


\section{Gh. NACU, M. POP, D. SIMEANU, Cristina RADU-RUSU, Roxana ZAHARIA, V. VINTILĂ}

pesticide residues. Gas chromatographic method.

SR EN ISO 16472:2006, Fodders. Determination of fibre content by treating with amylase and neutral detergent.

SR EN ISO 2171:2010, Cereals, vegetables and derived product. Determination of ash content by calcinations.

SR ISO 5983-1:2005, Animal feeding stuffs. Determination of nitrogen content and calculation of crude protein content (n.d.), Part 1: Kjeldahl method.

SR EN ISO 6497:2005, Fodders. Sampling.

SR EN ISO 6865:2002, Fodders.
Determination of crude fibre content. Method with intermediate filtration.

SR EN ISO 6869:2002, Fodders. Determination of calcium, copper, iron, magnesium, manganese, potassium, sodium and zinc content. Atomic absorption spectrometry method.

SR ISO 6492:2001, Fodders. Determination of fat content.

SR ISO 6496:2001, Fodders. Determination of humidity content and other volatile substances.

SR ISO 6498:2001, Fodders. Samples preparation for analysis

SR ISO 712:2010, Cereals and cereal products. Determination of humidity (Practical reference method). 